\title{
Attitude toward auditing, marketing and corporate governance (An examination based in Parsons' social action theory)
}

\author{
Gholamhossein Mahdavi and Abbas Ali Daryaei*
}

\begin{abstract}
Auditing develops within a social context. On the basis of Parsons' social action theory, we examine whether auditors' attitude toward marketing activities influences the time balance between auditing and marketing activities and attitude toward the importance of corporate governance mechanisms. We use survey responses from 257 auditors in Iran. We conducted our analysis by applying a binary Probit regression and for additional analysis, we utilize neural networks.

Attitude toward marketing has a positive significant relationship with balance time between auditing and marketing activities. And the attitude of auditors toward marketing has a positive significant relationship with attitude toward corporate governance. Also, the results showed a significant difference between industry expert auditors' attitude and other auditors toward marketing activities. Finally the results of this paper generally suggest that if artificial neural networks are employed in the prediction process, more reliable results will be achieved. The paper provides important insights into emerging issues and developments in auditing and marketing that have clear relevance to auditing research and practice. Drawing on our analytical framework, we provide directions for further opportunities for research of social theories and auditing.
\end{abstract}

Keywords: Attitude, Auditing, Corporate Governance Mechanism, Marketing, Parsons' Social Action Theory

\section{Introduction}

The basic objective of business is to develop, produce and supply goods and services to customers (Ishak et al. 2013; Miglani et al. 2015). Thus, the relationship between business and society is one of the most significant current discussions in economics and sociology. Previous studies on the balance between the interests of all stakeholders have shown that a lack of clear conceptual framework has been one of the main problems regarding the attitude and consequently the behavior of auditors (Broberg et al. 2013). However, in other areas of the social sciences, such as sociology, several researchers have attempted to provide a conceptual framework for relationships between parties. One of these people was Parsons. According to Parsons, social action is the subject of study of all humanity sciences, and in his view, the concept of system is very important for scientific knowledge,

\footnotetext{
* Correspondence: a.a.daryaei@soc.ikiu.ac.ir

School of Economics, Management \& Social Sciences, Shiraz University, Eram Academic Complex, Shiraz, Iran
}

and considers the systematic analysis capability for human action (Roche 1998).

Durkheim (1933), as someone, in whose work, one can find intellectual roots of functionalism, believes that through a process, density is put aside more mechanically and is replaced organically (naturally) by an organized community. Organic social organization is a more specialized society in which people pursue various occupations. However, people develop separate identities and the point of view of some about the world is a bit different from others. In this type of community, individuals' performance and groups, which are rooted in the specialized nature of jobs and in their nature change. This specialization is also applicable in the field of auditing.

With regards to change in the nature of accounting and auditing in accordance with what Fogarty has discussed based on Parsons' social action theory, the structure and function of auditing in the legal field must be revised. Changes in the nature of a profession need to be considered due to the contacts it has with other social 
structures in the issue of legislation and judgments. This is because actors of each function are intimately linked. This issue led to the fact that in 1997, the US Supreme Court in Arizona State approved a law, according to which professional organizations could no longer prohibit their members from carrying out their propaganda. At present, advertising and marketing are being considered as factors that can provide the required structures and functions for the interaction between auditor and client.

Marketing plays an important role in the closeness of consumer needs and characteristics of the product or services provided by the seller and issues such as advertising and pricing are entwined with it. These two factors, that is, the seller and the buyer in the economic structure, with a function such as marketing, are related to each other. The basic question is whether there is a relationship between the auditor and the client based on marketing process, or the parties are damaged due to disruption in some inherent properties of the auditor such as independence. According to Parsons's theory of social action, the auditors shall be able to create a balance between their needs and others. In the meantime, the role of personality traits of auditors or even their gender can affect their performance (Alavi Tabari et al. 2012; Tremblay and Malsch 2016).

A group of sociologists, such as Parsons, believed that the division of gender roles is natural, or consider a specific function for it, like the school of structural functionalism. Parsons has been a staunch supporter of the division of gender roles and believes that a nuclear family can only achieve its maximum functions when there are differences in instrumental roles (including manhood states) and expressive roles (womanhood states). Parsons separates family roles based on gender and believes that the acquisition of skills and expertise in the field of family roles must be according to the natural and potential talents of members that are inevitably different, and its difference is driven by the specific physical and mental structures of both sexes (Roche 1998). Respectively in the first order, the family, societies in general and in particular the economic society, are affected by attitudes of women. Because of substantial differences with men, women may have different attitudes and behaviors in the same situation as compared with men. Auditing as the economic performance of a part of the community is no exception to this general rule. Therefore, the question regarding the gender of respondents, in order to assess their attitudes in this study was also based on these concepts.

What happens when the company loses its entire property? Who do shareholders believe to be in charge of such incident? What is the role of auditors in preventing the occurrence of such events? Most stakeholders of a company are yet to determine answers to these aforementioned questions. Based on the writings of Parsons, there is only one convincing answer and that is the formulation of an improper structure and consequently, a poor performance. In response to the poor performance and structure and in order to strengthen the relationship between the company and other stakeholders, corporate governance has received a lot of attention in recent years (Black et al. 2006; Cornett et al. 2008; Mahdavi and Daryaei 2015). A positive attitude toward corporate governance facilitates the relationship between the stakeholders of the company and thus proper function. However, a research on attitudes toward corporate governance, social responsibility and the audit market could help explain the unknown dimensions of the problem. According to Parsons's social action theory, the determination of the optimal relationship between auditor and client is crucial. This is done through the investigation of attitude of auditors toward professional activities. The main objective of this study was to test the Parsons's social action theory about Iranian auditors. To achieve this, based on the earlier research, three components of attitudes, entrepreneurship and corporate governance were applied.

In the following section we provide a background and develop hypotheses. In subsequent sections we describe our research design, empirical analyses and results, additional analyses, and finally discuss those results.

\section{Background and hypothesis development}

"Given the traditional view on the distance between professional auditing engagements and marketing, changes in auditors' business environment suggest that the interests of professionalism should create room for other activities such as marketing" (Broberg et al. 2013: 67). Auditing develops within a social context. During the last century, society was always of the opinion that auditors are to detect fraud, with the auditing profession changing its path from the detection of fraud to the other side that is, denying this responsibility. Prior to 1920, fraud detection was known as the primary objective of auditing, which is clear from the view of the then auditing literature. Clow et al. (2009), in a research, compared the tendencies of auditors for marketing in year 1993 with 2004. The results of their study showed that a negative perception of auditors regarding marketing has turned into positive tendencies. This change in tendencies of auditors toward marketing intensified with more use of marketing activities and auditors improved their relations with customers.

This study tends to examine whether a balance between attitudes toward marketing and auditing activities can affect auditing as a profession. Here, the main question is that can a large number of audit firms and competition among them cause marketing activities to increase their share in the market? Meanwhile, this cannot pose adverse effect on the process of their professional activities. Also, the important point for auditors, as representatives of stakeholders, is on how to benefit from corporate governance mechanisms 
for more effective implementation of their tasks such as validation. The same way as the strengthening of corporate governance mechanisms is effective on the quality of financial reporting (Kent and Stewart 2008), it seems that this issue, potentially affects the decisions and judgments of auditors in various stages of auditing work and vice versa. The judgment of the auditors regarding the industry and auditor-client market characteristics is also effective on the correction or improvement of corporate governance mechanisms (Hassas Yeganeh and Dadashi 2011).

\section{Auditor's industry specialization}

Ishak et al. (2013) seek to understand the relationship between the concentration of the audit market and Auditor's Industry Specialization in the view of auditing in Malaysia. There are notes in this regard as follows: four large auditing firms in Malaysia, were in control of $72 \%$ market share of audit market in 2003; while most of the clients pay average audit fees, they had low income and their assets were of average size. Moreover, in the context of auditor's industry specialization, unlike the American and Australian counterparts, none of the four large audit firms in Malaysia are specialists in a particular industry. This is the same concept that makes it possible to, besides separating the specialist auditors and others, increase the validity of studies, including the present study.

Sarwoko and Agoes (2014) showed that auditor's industry specialization has influence on financial and high quality auditing in detecting fraud, this is because deep perception and high auditor's experience in special industry of client in the processes of business, business risks and important deviation risk in financial statements plays an important role. The ability of the auditor in such special fields of the client makes him/her able to select and implement ways of effective audit to discover important fraud cases and this could lead to increase of the audit quality. Yuan et al. (2016) investigated the relationship between the client business strategy and audit quality resulting from the auditor's industry specialization. Their investigation sample was Chinese companies between years 2000 and 2010. The results showed that there is a significant negative relationship between Auditor's Industry Specialization and optional commitment items of client. In other words, Auditor's Industry Specialization improves financial performance of client and the transparency of financial statements. However, the above study emphasized the overall interactions of the client with specialized audit procedures that may affect audit quality.

\section{Advertising and marketing strategies in auditing}

Hay and Knechel (2010) explained the relationship between marketing activities and auditing in New Zealand. They stated the importance of education and professional accountants believe that audit crisis in the last several years has been rooted in deregulation of the government which caused audit firms to advertise their services and find new customers on their own, thereby making the audit firms to follow a commercial approach. Numerous researchers have emphasized that deregulation of the government on advertising and demands has led auditors to act more competitively, and this can be attributed to lack of related professional skills, which is related to the auditors' recent wave of failure in the world (Healy and Palepu 2003; Palepu and Healy 2003). In other words, the auditor is expected to report questionable accounting procedures and significant errors and violations. In fact, this issue reminds professional competency and auditor's independence. The likelihood of discovery of the breach of contract by the auditor depends on the auditor's competence and the possibility of reporting violations discovered, and his independence. Market support of the auditor and, in fact, the demand for audit services continues until he/she is able to detect and report cases of breach of contract (Watts and Zimmerman 1986).

Broberg et al. (2013) in Sweden investigated the relationship between attitude toward audit activities and marketing among auditors. The results of their study showed that, from the conventional viewpoint of the gap and difference between professional auditing contributions and marketing, some changes have been created in the business environment of auditors that show specific interests, and have provided opportunities for other activities such as marketing. After the abolition of the statutory audit in 2010 in Sweden, it became more important for auditors. The results of the aforementioned study showed that auditors in Sweden have adjusted to new market conditions and have positive attitude toward marketing, as well as understanding the importance of marketing as part of professional responsibility. The studies of Broberg et al. (2013) showed that auditors with a positive tendency to marketing and the auditors, who assume that marketing is important, are largely able to strike a balance between time spent for inherent tasks of auditing and marketing activities.

Research findings have indicated that auditors create a balance between audit responsibilities and imposed marketing activities. Studies have investigated several ways of improving the auditing profession and pointed out that accepting marketing as an important part of professional services is essential in this regard. In addition, previous research has pointed to the fact that the notion of different activities among the auditing professions depends on the age of auditors (Clow et al. 2009). Therefore, it would be interesting to examine how the tendencies of auditors have changed in Sweden. Customer attraction dimension can also be other areas of the audit profession that has an effect on the perspective of auditors on sales and sales growth. Moreover, it is important to understand how changes in tendencies to marketing in the auditing profession can 
have an effect on audit quality. It is noteworthy that Broberg et al. (2013) evaluated the attitudes of auditors regarding marketing activities and audit using a questionnaire. In this questionnaire, they addressed variable making, and through explicit regression equations, investigated the effect of independent variables on the dependent variable.

Marketing strategy involves issues such as pricing, sale and distribution of a product or service. A company benefiting from market development strategy can acquire a significant market share of current products and services through market saturation and market penetration, and create new markets for current products and services (Khorshidi and Moghaddami 2002). Audit firms also, can use the same strategy to improve the quality of services provided and expand the market of their respective activities as well. The relationship between audit firms and clients is a kind of agreement, in terms of marketing concepts, that happens within a period of time. These agreements take place in the form of concluding auditing agreements and contract.

\section{Personality traits of auditors}

Entrepreneurship and gender of auditors are related to the part of auditors' character and the part that affects their character. Entrepreneurship and audit activities over a long period will lead to social development of humanity. Audit plays an important role in improving and increasing the transparency of business environment, especially since ancient times, when ways to better manage assets have been developed. At present, basically accounting and auditing has been defined as a science that moves towardits evolution even after thousands of years. The term "audit" is derived from the Latin word listening; however, it is used on a large scale since the Assyrians and Egyptians. Homocianu and Airinei (2014) showed that the dynamic and responsible nature of financial auditors in the role of experienced and professional entrepreneurs can remove the urgent needs of each company to offer fair financial reports and statements in accordance with legal frameworks that investors, creditors, government and people benefit from. Also, the results of their study showed that the need to provide services with a high level of objectivity will force audit firms to take advantage of entrepreneur auditors. In accordance with the professional and ethical requirements, entrepreneur auditors design and implement the audit work to further increase confidence in the audit reports content.

An entrepreneur, who is a person with a capitalism spirit, is able to provide the necessary resources to perform various acts. Entrepreneurship skills and attitudes often exist in the nonprofit sectors, but at present, due to changes in business approaches, entrepreneurs are the key solution to financial and non-financial problems of organizations. Popescu et al. (2015) showed that in the study of entrepreneurship in a modern competitive economy, no profession is more suitable than financial audit profession. Financial audit is the real meaning of an entrepreneur. Their fate and that of their client is in their own hands. Due to the independence necessary for their work, professional and ethic codes require that he does not sound like company employees by whom he is audited. The results of their research showed that with increasing competition among auditors, the marketing process that introduces the skills and competencies of auditors in Romania is based on the issue that by attracting entrepreneur auditors, one can get a good share in the audit market.

Entrepreneur auditors were determined based on questionnaires and interviews. Another issue that may affect the fee is the gender of auditors. Huang et al. (2015), in a research, sought to answer the question on whether female audit partners received lower fees than male counterparts in the process of auditing or not? By examining the data on audit fees in Taiwan between 2002 and 2011 where the name of independent auditor partners were mentioned, they found that the audit fees for female partners is significantly less than that of the male counterparts. Furthermore, they explained that the difference between audit fees in industries where fewer female partners are present is more intense and cannot be explained through audit quality and delay in audit report, and despite controlling constant effective factors, this difference in fees still remains. Their findings also provide evidence that there is discrimination against female partners regarding audit fees in Taiwan. This indicates that attitude toward female auditors and consequently the attitude of female auditors to the process of auditing is different from that of their male counterparts.

\section{Corporate governance and auditing}

Öhman et al. (2012) conducted a research with the aim of creating, testing and improving a structural equation model for the satisfaction of client from the audit and client's perceptions of the usefulness of audit outside the organization stakeholders. Accordingly, a questionnaire was posted to clients, that is, Swedish limited liability company managers with more than 50 employees or more. The results showed that there is a strong relationship between the client satisfaction and usefulness outside the organization stakeholders. The competency of the independent auditor is positively related and his doubt is negatively related to the satisfaction of the clients and the auditor and usefulness for stakeholders outside the organization. The present study, only discussed the levels of the auditor and the audit team, and used a limited number of independent variables. These findings support the results of previous study and demonstrated that 
client relationships with independent auditors and auditor assistants have a positive effect on client satisfaction, but has no significant relationship with stakeholders outside the organization. As a result, it is better to consider the organization audit teams, where different members have distinct roles. This study also showed that most audit studies are yet to be evaluated explicitly. In other words, this study evaluated the distinction between the client satisfaction with audit and client understanding of the usefulness of auditing to stakeholders outside the organization, which is something novel in this respect.

Companies are increasingly looking to stand out their positive cooperation in social activities so as to exhibit the good image of the company and gain legitimacy. The concept of legitimacy enables researchers to explain social relations of an organization. According to this definition, from the mutual interaction of the organizations with society, legitimacy theory emerges. Therefore, the level of congruence between the company and the expectations of society, due to the company's activities, represents a direct reflection of the company's legitimacy (Malekian et al. 2015: 330). Ducassy (2015) examined the relationship between some of the mechanisms of corporate governance and social responsibility of companies. He showed that the explanation of good communication between all stakeholders, based on agency and theory of stakeholders, can strengthen the social responsibilities of the company. In this regard, some mechanisms such as ownership concentration and the CEO duality have more effect on improving corporate social performance. In this study, the role of auditors and their attitude toward corporate social responsibility for persuading company managers in order to improve corporate social performance is emphasized.

Cao et al. (2015), after offering standards of risk-based audit, instead of internal control-based audit, investigated the changes in China's audit strategy. In particular, considerations were made on whether the auditors use riskbased audit approach to evaluate corporate governance before the release of audit resources or not? Their results showed that in the internal control based-audit method, there is a weak relationship between audit efforts and corporate governance. However, the implementation of a risk-based approach, which is obligatorily based on the new auditing standards, significantly strengthened the relationship between corporate governance and auditing efforts. Further, they pointed out that ever since the change in the auditing method, ten large auditing firms came into existence, which have demonstrated a better understanding of governance risk as compared with smaller firms, and perform their audit efforts on this basis. Empirical evidence suggested that auditors have changed their audit strategy to comply with laws and regulations, and riskbased auditing is partly accepted. Also, logical and efficient corporate governance contribute to optimization of the allocation of audit resources. In particular, audit firms should strengthen their risk-based auditing capabilities. In general, their findings showed that the vicious circle toward risk-based audit optimizes audit efforts in China.

Given the theoretical and empirical evidence, the present study's hypotheses about auditors' attitude are specified as follows:

H1: Auditors' attitude toward marketing activities influences the time balance between auditing and marketing activities.

H2: A significant difference is found between industry expert auditors' attitude and other auditors toward marketing activities.

H3: Auditors' attitude toward marketing activities influences their attitude toward the importance of corporate governance mechanisms.

\section{Research design}

Survey research is one of the most important areas of measurement in applied social and business research. The broad area of survey research encompasses any measurement procedures that involve asking questions about respondents. The present study is one of the types of survey research. This section describes the research method, beginning with a discussion of the sample selection process and descriptive statistics for the sample. Followed by presentation and discussion of the survey, including how variables are operationalized and finally, we specify the regression models. In the subsequent section, the results from the statistical analyses are presented and the findings are discussed. The sample consisted of Iranian association of certified public accountants (IACPA) members which were calculated using the Cochran's sample size formula. The total number of registered member in November 2014 was 2084 (see, http://www.iacpa.ir/).

To collect data for hypotheses testing, this study used a questionnaire adapted from the studies of Broberg et al. (2013), Biech (2007), as well as literature review and document analysis. This questionnaire was designed to collect data related to perceive marketing as a concern for IACPA. The questionnaire also included items related to auditor perceptions regarding the responsibility to balance the time between auditing and marketing activities. To analyse the data gleaned from the survey, this study employed binary Probit regression and artificial neural networks in the prediction process. By collecting data from IACPA, this study provides insights that had previously been absent from the studies outlined above.

All items in the questionnaire were in Iran to avoid misinterpretations, an issue that would otherwise decrease the measurement validity of the results. Although the approach of this study is explorative in nature, this study intends to uncover the relationships and patterns on which quantitative methods could help to shed light. An 
exploratory interview was conducted with an authorized auditor prior to the distribution of the questionnaire in order to check whether our questions were understood in the way we intended. As a result, some questions were rephrased and a few background questions were removed from the original questionnaire. The final questionnaire is presented in the Appendix.

From the initial sample, a total of 257 respondents submitted their answers (a response rate of $79 \%$ ). Of the 257 respondents, there were 31 females (12\%) and 226 males (88\%). The average age of the respondents was 45 , ranging from 25 to 73 years, and the average number of years as approved or authorized auditor was 15 , with a minimum of 5 and a maximum of 30 years. The information on the background of respondents is shown in Table 1.

The questionnaire was divided into five parts. The first part included four background (demographic) questions: gender, experience as authorized or approved public auditor, education and specialty. These items were all used as control variables. Gender was measured as male or female and used as a dummy variable in the analyses. Experience as approved or authorized auditor was

Table 1 Information on the background of respondents

\begin{tabular}{|c|c|c|c|}
\hline \multicolumn{2}{|l|}{ Description } & \multirow{2}{*}{$\frac{\text { No. }}{222}$} & \multirow{2}{*}{$\begin{array}{l}\text { Percentage } \\
88.39 \%\end{array}$} \\
\hline Gender & Male & & \\
\hline & Female & 35 & $13.61 \%$ \\
\hline & Total & 257 & $100 \%$ \\
\hline \multirow[t]{3}{*}{ Education } & BS & 169 & $65.75 \%$ \\
\hline & Graduate & 88 & $34.25 \%$ \\
\hline & Total & 257 & $100 \%$ \\
\hline \multirow[t]{5}{*}{ Field } & Accounting & 149 & 57.97 \\
\hline & Management & 64 & 24.90 \\
\hline & Economics & 33 & 12.85 \\
\hline & Other & 11 & 04.28 \\
\hline & Total & 257 & $100 \%$ \\
\hline \multirow[t]{5}{*}{ Age } & $25-35$ & 35 & $13.63 \%$ \\
\hline & $35-45$ & 104 & $40.46 \%$ \\
\hline & $45-55$ & 81 & $31.52 \%$ \\
\hline & $>55$ & 37 & $14.39 \%$ \\
\hline & Total & 257 & $100 \%$ \\
\hline \multirow[t]{5}{*}{ Experience } & $1-5$ & 22 & $08.56 \%$ \\
\hline & $5-10$ & 39 & $15.17 \%$ \\
\hline & $10-15$ & 83 & $32.29 \%$ \\
\hline & $>15$ & 113 & $43.98 \%$ \\
\hline & Total & 257 & $100 \%$ \\
\hline \multirow[t]{3}{*}{ Expertise } & industry-specialist auditors & 165 & $64.20 \%$ \\
\hline & Other & 92 & $35.80 \%$ \\
\hline & Total & 257 & $100 \%$ \\
\hline
\end{tabular}

measured on a continuous scale. Education, which was measured as a dummy variable, was coded 1 if graduate and 0 otherwise. In the fourth control variable, specialty was measured as a dummy variable, was coded 1 if the auditors were specialists and 0 , if otherwise.

The remainder of the questionnaire was divided into many subparts, asking the auditors about their perceived importance, attitude, and time spent on marketing and auditing activities, auditing business environment in Iran, attitude toward corporate governance and measurement of entrepreneurship. The respondents marked their opinion on a 7-point Likert scale ranging from "Strongly disagree" (1) to "Strongly agree" (7) for each of the 12 activities listed in the Appendix, which were derived from previous literature, as well as the explorative interview. Table 2 shows how the independent and dependent variables were constructed. Also, descriptive statistics are shown in Table 3.

Alpha was developed by Lee Cronbach in 1951 to provide a measure of the internal consistency of a test or scale; it is expressed as a number between 0 and 1 . As pointed out earlier, the number of test items, item interrelatedness and dimensionality affect the value of alpha. There are different reports about the acceptable values of Cronbach's alpha, ranging from 0.70 to 0.95 . A low value of alpha could be due to a low number of questions, poor interrelatedness between items or heterogeneous constructs (Tavakol and Dennick 2011: 54). In this study, Cronbach's Alpha, Test-Retest Reliability Coefficient and Split Half Reliability were calculated for corporate governance, auditing and marketing Component. All had values above 0.718 . And Pearson's correlations indicated the strength and direction of the relationships. The results are shown in Tables 4 and 5.

To test our hypotheses, a Binary Probit regression model, nonparametric tests and artificial neural networks with BT were employed. The measure of balance time and corporate governance (CG) attitude were used as the dependent variables, measures of auditors' attitude toward marketing activities, Auditor's view on the importance of marketing activities, as well as other known control variables from literature were used as the independent variables.

\section{Empirical analysis and results Tests of $\mathrm{H} 1$}

As shown in Table 6, Panel A, attitude toward marketing had a positive significant relationship with balance time between auditing and marketing activities at $90 \%$ level. Therefore, this hypothesis is confirmed. However, the attitude toward marketing by auditors without specialized training in the field of marketing can be effective in establishing a balance between auditing and marketing activities. Surveys have shown that auditing firms, as service firms, have characteristics of a commercial service firm in several 
Table 2 Explanation and measurement of variables

\begin{tabular}{ll}
\hline Variables & Measurement \\
\hline BT (balance time) & $\begin{array}{l}\text { The auditor must carefully balance time spent on the imposed marketing activities and the inherent tasks of the auditing } \\
\text { profession to make sure that trust and confidence in the profession are not damaged. BT was created by subtracting the } \\
\text { average scores for all auditing activities from the average scores for all marketing activities. We use a dummy variable } \\
\text { coded one if the balance time was upper then average scores and zero otherwise. }\end{array}$ \\
In the context of corporate governance, marketing is supportive of a stakeholder approach to clients but may be less \\
supportive of other stakeholders. Nonetheless, in this study, CG was created by questionnaire. We use a dummy variable \\
coded one if the CG was upper then average scores and zero otherwise. \\
Auditor's attitude toward marketing, used as an independent variable, was operationalized as an index of the average \\
scores for all the marketing activities in the attitude section of the questionnaire. The scores were added for each of \\
the respondents, and the sum was divided by the total number of activities. The variable was labeled "ATTITUDEM". \\
Auditor's attitude toward auditing, used as an independent variable, was operationalized as an index of the average \\
Scores for all the auditing activities in the attitude section of the questionnaire. The scores were added for each of the \\
respondents, and the sum was divided by the total number of activities. The variable was labeled "ATTITUDEA". \\
Expert auditors can contribute significantly to reduce costs and develop audit market. Specialty was measured as a \\
dummy variable was coded 1 if auditors were specialist and 0 otherwise. The variable was labeled "SPECIALITY". \\
An entrepreneur, who is a person with a capitalism spirit, is able to provide the necessary resources to perform various \\
acts. The entrepreneurship was constructed based on 22 questions pertaining to different entrepreneurship practices. \\
EX was created by questionnaire. We use a dummy variable coded one if the balance time was upper then average \\
scores and zero otherwise. \\
We classified respondents into male or female and we coded female as 0 and male as 1.
\end{tabular}

aspects, and auditors can use commercial development tools such as advertising and marketing activities as long as commercial activities and activities leading to business developments do not conflict with their main objective, which is fairly based on financial statements. This justifies and explains the significant relationship of attitude toward marketing activities by certified public accountants. This result is consistent with that of Broberg et al. (2013), but inconsistent with that of Griffin and Lont (2007). According to Parsons' theory, marketing is a function formed in the economic structure of auditors with other stakeholders. Therefore, this theory is true for Iranian auditors' attitudes and behavior; those who are able to accept changes in the scope of audit business.

For further analyses, we separate the samples by nature into 5 categories: inactive members of IACPA, auditors working at Iran audit organization, auditors working at audit firms, individual independent auditors, and auditors' partner of audit firms. Thus, the first hypothesis was then examined. The results are shown in Table 7.

\section{A) Inactive members of IACPA}

As shown in Table 7, the model was significant at $95 \%$ level. The independent variables predicted $15.3 \%$ of the variations of the BT variable. There was a significant positive relationship between attitude toward marketing by Inactive members of IACPA and balance time between auditing and marketing activities (significant at $99 \%)$. There was also a significant negative relationship between the entrepreneurship variable and balance time between auditing and marketing activities (significant at $99 \%)$. Therefore, the hypothesis is confirmed. The model testing results are consistent with those of Broberg et al. (2013), and Antoncic and Hisrich (2004) but inconsistent with those of Popescu et al. (2015).

Table 3 Descriptive statistics

\begin{tabular}{|c|c|c|c|c|c|c|}
\hline & $\mathrm{N}$ & Range & Minimum & Maximum & Mean & Std. Deviation \\
\hline CG & 257 & 7.00 & .00 & 7.00 & 6.0984 & .91809 \\
\hline Business & 257 & 4.63 & 3.00 & 7.63 & 5.8756 & .70818 \\
\hline BT & 257 & 1.00 & .00 & 1.00 & .4981 & .50097 \\
\hline Speciality & 257 & 1.00 & .00 & 1.00 & .5992 & .49101 \\
\hline EX & 257 & 1.00 & .00 & 1.00 & .5642 & .49683 \\
\hline GENDER & 257 & 1.00 & .00 & 1.00 & .1323 & .33947 \\
\hline ENTERPRENURSHIP & 257 & 14 & 8 & 22 & 15 & .89855 \\
\hline EDU & 257 & 1.00 & .00 & 1.00 & 1.5097 & .50862 \\
\hline Valid N (listwise) & 257 & & & & & \\
\hline
\end{tabular}


Table 4 Test-retest reliability coefficient and cronbach's alpha and split half reliability

\begin{tabular}{|c|c|c|c|c|c|}
\hline Questions & Component & Correlation Coefficient & Questions & Component & Correlation Coefficient \\
\hline Q1 & Corporate Governance & .877 & Q3 & Auditing & .826 \\
\hline Q2 & Corporate Governance & .735 & Q4 & Auditing & .927 \\
\hline Q3 & Corporate Governance & .855 & Q5 & Auditing & .983 \\
\hline Q4 & Corporate Governance & .899 & Q6 & Auditing & .971 \\
\hline Q5 & Corporate Governance & .935 & Q1 & Marketing & .867 \\
\hline Q6 & Corporate Governance & .947 & Q2 & Marketing & .910 \\
\hline Q7 & Corporate Governance & .904 & Q3 & Marketing & .975 \\
\hline Q8 & Corporate Governance & .837 & Q4 & Marketing & .791 \\
\hline Q9 & Corporate Governance & .920 & Q5 & Marketing & .699 \\
\hline Q1 & Auditing & .977 & Q6 & Marketing & .944 \\
\hline Q2 & Auditing & .915 & & & \\
\hline \multicolumn{2}{|c|}{ Component } & \multicolumn{2}{|l|}{ Cronbach's Alpha } & \multicolumn{2}{|c|}{ Split Half Reliability } \\
\hline \multicolumn{2}{|c|}{ Corporate Governance } & \multicolumn{2}{|l|}{.732} & \multicolumn{2}{|l|}{.798} \\
\hline \multicolumn{2}{|l|}{ Auditing } & \multicolumn{2}{|l|}{.811} & \multicolumn{2}{|l|}{.718} \\
\hline \multicolumn{2}{|l|}{ Marketing } & \multicolumn{2}{|l|}{.698} & \multicolumn{2}{|l|}{.729} \\
\hline
\end{tabular}

From the perspective of unemployed certified public accountants, the important point in studying the concept of balance time is marketing. Since auditing activities with the independence index is almost accepted among unemployed certified public accountants, what worries them is that informal marketing is palpable in the corporate environment and auditors understand this more than anyone else in the executive staff of the company. But the entrepreneurial attitude is not considered a factor to balance time between auditing and marketing activities or at least to explain it, due to the lack of training in the field of entrepreneurship in all business areas in Iran including auditing marketing. Thus, legislators must pay special attention to the professions of accounting and auditing and even clients.

\section{B) Auditors working at Iran audit organization}

As shown in Table 7, the independent variables predicted $17 \%$ of the variations in BT variable. There was a significant positive relationship between the attitude toward marketing by auditors working at Iran audit organization and balance time between auditing and marketing activities (significant at $99 \%$ ). Therefore, this study's hypothesis is confirmed. The results are consistent with those of Broberg et al. (2013), and Antoncic and Hisrich (2004)), but inconsistent with those of Popescu et al. (2015).

However, more caution should be made in generalizing the results. From the perspective of auditors working at Iran audit organization, the important point in studying the concept of balance time is marketing. Although the auditing activities with the independence index is almost accepted

Table 5 Correlations

\begin{tabular}{|c|c|c|c|c|c|c|c|c|c|c|}
\hline Variables & Attitudem & AttitudeA & BT & ImportantM & ImportantA & CG & EX & Gender & EDU & Speciality \\
\hline AttitudeM & 1 & .055 & -.037 & $.514^{\mathrm{b}}$ & .074 & $.146^{\mathrm{a}}$ & -.031 & .005 & $-.144^{\mathrm{a}}$ & -.061 \\
\hline AttitudeA & & 1 & -.078 & -.004 & $.164^{c}$ & .022 & -.064 & -.030 & .019 & .107 \\
\hline BT & & & 1 & -.039 & $-.133^{a}$ & .073 & $.154^{\mathrm{a}}$ & -.057 & -.010 & .003 \\
\hline ImportantM & & & & 1 & $.285^{c}$ & $.245^{\mathrm{b}}$ & .094 & .026 & $-.137^{a}$ & -.113 \\
\hline ImportantA & & & & & 1 & $.172^{c}$ & .049 & -.025 & .029 & -.029 \\
\hline CG & & & & & & 1 & .013 & .112 & -.040 & .058 \\
\hline EX & & & & & & & 1 & .074 & 0.79 & .040 \\
\hline GENDER & & & & & & & & 1 & .098 & -.011 \\
\hline EDU & & & & & & & & & 1 & .015 \\
\hline Speciality & & & & & & & & & & 1 \\
\hline
\end{tabular}

${ }^{\mathrm{a}}$ Correlation is significant at the 0.10 level (two-tailed), ${ }^{\mathrm{b}}$ Correlation is significant at the 0.05 level (two-tailed) and ${ }^{\mathrm{c}}$ Correlation is significant at the 0.01 level (two-tailed) 
Table 6 Binary probit regression results

\begin{tabular}{|c|c|c|c|c|}
\hline Variables & Coefficients & Standard error & Z-statistics & Prob \\
\hline ATTITUDEM & .1142 & .0653 & 1.7478 & .0805 \\
\hline ATTITUDEA & -.0807 & .1115 & -.7243 & .4688 \\
\hline SPECIALITY & -.0708 & .1621 & -.4371 & .6620 \\
\hline ENTERPRENEURSHIP & -.1750 & .1324 & -1.3215 & .1863 \\
\hline EX & .1650 & .1614 & 1.0223 & .3066 \\
\hline GEN & .2855 & .2355 & 1.2125 & 2253 \\
\hline$E D U$ & .01294 & .1626 & .7954 & .4264 \\
\hline \multicolumn{5}{|c|}{$\begin{aligned} \text { Panel B: } & C G_{i}=a_{i}+\beta_{1} \text { ATTITUDEM } \\
& +\beta_{4} E X_{i}+\beta_{5} \text { ATEN }_{i}+\beta_{6} E D U_{i}+\mu_{i}\end{aligned}$} \\
\hline Variables & Coefficients & Standard error & Z-statistics & Prob \\
\hline ATTITUDEM & .2109 & .8175 & 2.5804 & .0099 \\
\hline ATTITUDEA & -.1631 & .0738 & -2.2078 & .0273 \\
\hline SPECIALITY & .2224 & .1610 & 1.3813 & .01672 \\
\hline EX & -.0073 & .1607 & -.0454 & .9638 \\
\hline GEN & -.0752 & .2353 & -.3197 & .7491 \\
\hline EDU & Deleted & Deleted & Deleted & Deleted \\
\hline
\end{tabular}

among auditors working at Iran audit organization, what worries them is informal marketing which is palpable in the corporate environment and auditors understand this more than anyone else in the executive staff of the company. But entrepreneurial attitude is not considered a factor to balance time between auditing and marketing activities or at least to explain it, due to lack of training in the field of entrepreneurship in all business areas in Iran including auditing marketing. Thus, legislators must pay special attention to the professions of accounting and auditing and even clients.

The concern of this type of auditors for auditing marketing concepts is a very important and promising point in the acceptance of marketing processes in the IACPA. This means that the old perception of marketing, as a means to prefer the interests of some stakeholders to others, has failed.

\section{C) Auditors working at audit firms}

As shown in Table 7, the independent variables predicted $16.3 \%$ of the variations of the BT variable. There was a significant positive relationship between attitude toward marketing by auditors working at audit firms and balance time between auditing and marketing activities (significant at $99 \%$ ). Therefore, the hypothesis is confirmed. The results are consistent with those of Broberg et al. (2013), and Antoncic and Hisrich (2004). However, more caution should be made in generalizing the results. From the perspective of auditors working at audit firms, the important point in studying the concept of balance time is marketing, because auditing activities with the independence index is almost accepted among auditors working at audit firms, in particular, in Iran where market concentration in the auditing profession is challenging and a concern for various auditing firms (Personal communication, January 20, 2015) A significant percentage of the auditing market share is in the hands of a few known audit firms and in this regard, different studies have failed to suggest scientific reasons such as raising the quality of auditing and improved company performance (Stiglbauer and Velte 2012).

\section{D) Individual independent auditors}

As shown in Table 7, the model was not significant at the $95 \%$ level. Thus, the first hypothesis is rejected. This may be attributed to the small sample size (13 people) in this study.

\section{E) Auditors' partner of audit firms}

As shown in Table 7, independent variables predicted $12.9 \%$ of the variation of the BT variable. There was a significant positive relationship between the attitude toward auditors' partner of audit firms and balance time between auditing and marketing activities. The model testing results are inconsistent with those of Broberg et al. (2013) and Antoncic and Hisrich (2004). However, since there was no significant relationship between attitude toward marketing and balance time between auditing and marketing activities, the first hypothesis is rejected. From the perspective of auditors' partner of audit firms, as long as there is no positive view to the auditing marketing process by the legislators, changes in the auditing process cannot occur and marketing will not be accepted as a part of this process, as confirmed by several researchers (Chaney et al. 2003; Miglani et al. 2015; Popescu et al. 2015; Rahmina and Agoes 2014; Steponaviciute et al. 2010).

\section{Tests of $\mathrm{H} 2$}

As shown in Table 8, the Mann-Whitney $U$ test was used for hypothesis testing due to non-normal distribution of two variables, attitudes toward marketing and independent samples testing. The results showed a significant difference between industry expert auditors' attitude and other auditors toward marketing activities. By applying the theory of Parsons social action, it was shown that industry expert auditors can contribute significantly to reduce costs and develop audit market due to their awareness of industry concerns and the fact that their expertise would lead to better interaction with clients. Specialized auditors' positive attitude can consider the interests of all stakeholders. Therefore, specialization of audit firms by auditors who have the experience of working in specialized audit firms could be a logical step to reduce the concentration of the audit market and improve understandable relations among all stakeholders. The results of this hypothesis are inconsistent with those of Chen and Liang (2014).

\section{Tests of $\mathrm{H} 3$}

From the results shown in Table 6, Panel B, it is obvious that the attitude of auditors toward marketing had a 
Table 7 Binary probit regression results: $B T_{i}=a_{i}+\beta_{1}$ ATTITUDEM $M_{i}+\beta_{2}$ ATTITUDEA $_{i}+\beta_{3}$ SPECIALITY $_{i}$ $+\beta_{4}$ ENTERPRENEURSHIP $+\beta_{5}$ EX $+\beta_{6}$ GEN $+\mu_{i}$

\begin{tabular}{|c|c|c|c|c|c|c|c|}
\hline \multicolumn{8}{|c|}{ Panel A: Inactive members sample } \\
\hline & AttitudeM & AttitudeA & Speciality & Enterpreneurship & EX & GENDER & \\
\hline B & 39.678 & .189 & .160 & -1.121 & -.136 & 1.017 & Nagelkerke R Square \\
\hline S.E. & 15.279 & .510 & .448 & .440 & .448 & .651 & .163 \\
\hline Wald & 6.744 & .137 & .127 & 6.503 & .092 & 2.436 & Cox \& Snell R Square \\
\hline Sig. & .010 & .711 & .721 & .011 & .762 & .119 & .122 \\
\hline \multicolumn{8}{|c|}{ Panel B: Auditors working at Iran audit organization sample } \\
\hline & AttitudeM & AttitudeA & Speciality & Enterpreneurship & EX & GENDER & \\
\hline B & 29.00 & .359 & -.274 & -.376 & -1.236 & -10.33 & Nagelkerke R Square \\
\hline S.E. & 8.03 & .845 & .745 & 1.959 & .925 & 4.254 & .170 \\
\hline Wald & .031 & .181 & .135 & .037 & 1.785 & 5.89 & Cox \& Snell R Square \\
\hline Sig. & .002 & .671 & .713 & .848 & .181 & .003 & .127 \\
\hline \multicolumn{8}{|c|}{ Panel C: Auditors working at audit firms sample } \\
\hline & AttitudeM & AttitudeA & Speciality & Enterpreneurship & EX & GENDER & \\
\hline B & 13.45 & 12.25 & -.399 & -1.332 & -15.100 & -.370 & Nagelkerke R Square \\
\hline S.E. & 4.49 & 8.123 & .732 & .955 & 7.001 & .705 & .153 \\
\hline Wald & 8.973 & 2.274 & .297 & 1.945 & 4.651 & .276 & Cox \& Snell R Square \\
\hline Sig. & .001 & .220 & .586 & .163 & .023 & .600 & .114 \\
\hline \multicolumn{8}{|c|}{ Panel D: Individual independent auditors sample } \\
\hline & AttitudeM & AttitudeA & Speciality & Enterpreneurship & EX & GENDER & \\
\hline B & .281 & 2.099 & -1.383 & 3.423 & -2.313 & Deleted & Nagelkerke R Square \\
\hline S.E. & .813 & 3.846 & 1.456 & 4.211 & 1.787 & Deleted & .395 \\
\hline Wald & .120 & .298 & .901 & .661 & 1.676 & Deleted & Cox \& Snell R Square \\
\hline Sig. & .729 & .585 & .342 & .416 & .196 & Deleted & .291 \\
\hline \multicolumn{8}{|c|}{ Panel E: Auditors partner of audit firms sample } \\
\hline & AttitudeM & AttitudeA & Speciality & Enterpreneurship & EX & GENDER & \\
\hline B & .166 & 3.475 & .334 & -.742 & -.031 & 1.097 & Nagelkerke R Square \\
\hline S.E. & .181 & 1.25 & .380 & .338 & .365 & .611 & .129 \\
\hline Wald & .835 & 7.728 & .771 & 4.825 & .007 & 3.221 & Cox \& Snell R Square \\
\hline Sig. & .361 & .002 & .380 & .028 & .932 & .073 & .101 \\
\hline
\end{tabular}

positive significant relationship with attitude toward corporate governance at $99 \%$ level. Moreover, the attitude of auditors toward auditing activities had a significant negative relationship with attitude toward corporate governance at $95 \%$ level. To elaborate this, we re-examined the concept of corporate governance collection. Corporate governance

Table 8 Nonparametric tests results

\begin{tabular}{lllll}
\hline SPECIALITY & & N & $\begin{array}{l}\text { Mean } \\
\text { Rank }\end{array}$ & $\begin{array}{l}\text { Sum of } \\
\text { Ranks }\end{array}$ \\
\hline AttitudeM & BA & 127 & 142.26 & 18066.50 \\
& UPBA & 129 & 114.96 & 14829.50 \\
Total & & 256 & & $\begin{array}{l}\text { Asymp. Sig. } \\
\text { (2-tailed) }\end{array}$ \\
& & & & .003 \\
Test Mann-Whitney U & 6444.50 & Wilcoxon W & 14829.5 & .003 \\
Statistics & & & & \\
\hline
\end{tabular}

had nothing to do with the company's operations management but to the firm leadership, monitoring and controlling the actions of the executives and their accountability to all stakeholders. This shows that auditors with a positive attitude toward marketing maintain the interests of managers by performing marketing activities, and also find the desired client and make better judgments based on their expertise and agreement on the fees. Undoubtedly, this also affects the attitude of auditors to corporate governance environment. However, to some extent, the attitude of auditors to the client's corporate governance is influenced by their attitude toward marketing. This finding is consistent with the result of Broberg et al. (2013) and Chaney et al. (2003).

Although the attitude of auditors to auditing activities may increase the quality of auditing by increasing the independence of auditors (Alavi Tabari et al. 2012; Arel 2012), but it 
could weaken the attitude of auditors to the development and improvement of corporate governance because the sole attitude toward auditing activities may not consider the interests of all stakeholders which can show itself through increased auditing costs.

Parsons emphasized on the complex social relationship of humans in all his works (Roche 1998). Since social action is meaningful, it is inevitably in the guise of symbolism. Through signs and symbols, the actor identifies his/her environment, feels, evaluates, and manipulates it and interacts with other actors. Corporate governance and auditing environment are established in a shared space and have always been effective in the evolution process of firms. When there is a positive and significant relationship between attitude toward marketing and attitude toward corporate governance, it means that by establishing an appropriate structure of corporate governance, one can witness the proper functioning of accountability and therefore, observe the rights of all stakeholders. Results of the third hypothesis testing have re-emphasized the validity of parsons' theory in IACPA.

\section{Additional analyses}

"Neural networks are advanced modeling techniques, which are capable of modeling complex functions. Neural networks are nonlinear." (Etemadi et al. 2015: 57). The use of neural networks for regression analysis problem showed several appealing advantages as compared with traditional statistical methods, such as linear regression. DeTienne et al. (2003) discussed the main features of neural networks when compared with linear regression. First, a considerable undesirable feature of linear regression is that it cannot deal with non-linear relationships among variables. Neural networks, on the other hand, can effectively model non-linear relationships. Second, the performance of linear regression models depends on various assumptions such as absence of multicollinearity, and normally distributed residuals with zero mean and constant variance. However, these assumptions are not required with neural networks (Höglund 2015). Hence, based on the above analyses, the prediction power of the Probit regression was compared with MLP prediction results in the artificial neural networks according to the first and third hypothesis. MSE (Mean Squared Error) performance criterion was adopted for determining the prediction power of probit regression.

$$
M S E=\frac{\sum_{t=1}^{t=n}\left(\hat{Y}_{t}-Y_{t}\right)^{2}}{n}
$$

Where:

$Y_{t}=$ CG dependent variable

$\hat{Y}_{t}=$ CG prediction variable. This variable was calculated in a way that the coefficients of the research variables were extracted from Probit regression output. Then, a prediction was calculated for CG variable for each respondent separately and according to the model.

$\mathrm{n}=$ number of respondents

Neural networks are models of biological neural structures. This neuron consists of multiple inputs and a single output. Each input is modified by a weight, which multiplies with the input value. The neuron will combine these weighted inputs and, with reference to a threshold value and activation function, use these to determine its output. This behavior follows closely our understanding of how real neurons work. One of the most common neural network models is based on multilayer perceptron (MLP). The basic structure of a MLP is one input layer, one or more hidden layers and one output layer. Each of these layers comprises one or several nodes. The structure of the input and output layers is rather straight forward. That is, the input layer has as many nodes as there are in the independent variables and correspondingly, the output layer has as many nodes as there are in the dependent variables. The schematic view of the neural network structure is shown in Fig. 1.

The ROC curve presented a visual display of the sensitivity and specificity for all possible cut-offs, in one plot, and gave clear and powerful result as compared with other Tables used for analysis. In the graph of sensitivity and specificity, sensitivity represented the number of positive cases correctly classified and specificity represented the number of negative cases incorrectly classified as positive. Both lines were on the top left corner close to 1 , which indicates that the model is best fit. Figure 2 shows the ROC curve.

The graph of the classification box showed the predicted pseudo-probability of the correctly classified cases of categories: "zero" and "one". Incorrect classified cases of both categories were observed below the cut point 0.5 . Figure 3 shows the predicted pseudo probabilities. The first hypothesis figures were not presented in this study to avoid prolongation of sentences. However, the results are shown in Table 9.

Table 9 shows the results of the analyses as regard the figures and MSE value for the first and third hypotheses. For the first hypothesis, an investigation of the aforesaid Table showed that the prediction power of Probit regression and MLP is respectively 0.52 and 0.85 . The MLP prediction power may of course be improved through a learning process. MLP sensitivity was also 0.74, which is greater than that of the Probit regression model. Also, as regard the third hypothesis, an investigation of the aforesaid Table showed that the prediction power of the Probit regression and MLP is 
respectively 0.48 and 0.67 . The MLP prediction power may of course be improved through a learning process. MLP sensitivity was also 0.70 , which was greater than that of the Probit regression model. The results of this section generally suggest that if the artificial neural networks are employed in the prediction process, more reliable results will be achieved.

\section{Conclusion}

Auditors must confront these questions in running their businesses, just as individuals must in leading their everyday lives. Corporate social responsibility and appropriate interaction with stakeholders in short, is not an empty box. But what exactly is in the box? This is the most important question of our study. From social science perspective, to this question one answer is possible. Thus, we employed Parsons' social action theory answer to the vital question. We conducted our analysis by applying a binary Probit regression. Then we utilize neural networks for additional analysis. The results of this section generally suggest that if artificial neural networks are employed in the prediction process, more reliable results will be achieved.

Attitude toward marketing had a positive significant relationship with balance time between auditing and marketing activities personality traits of auditors, regardless

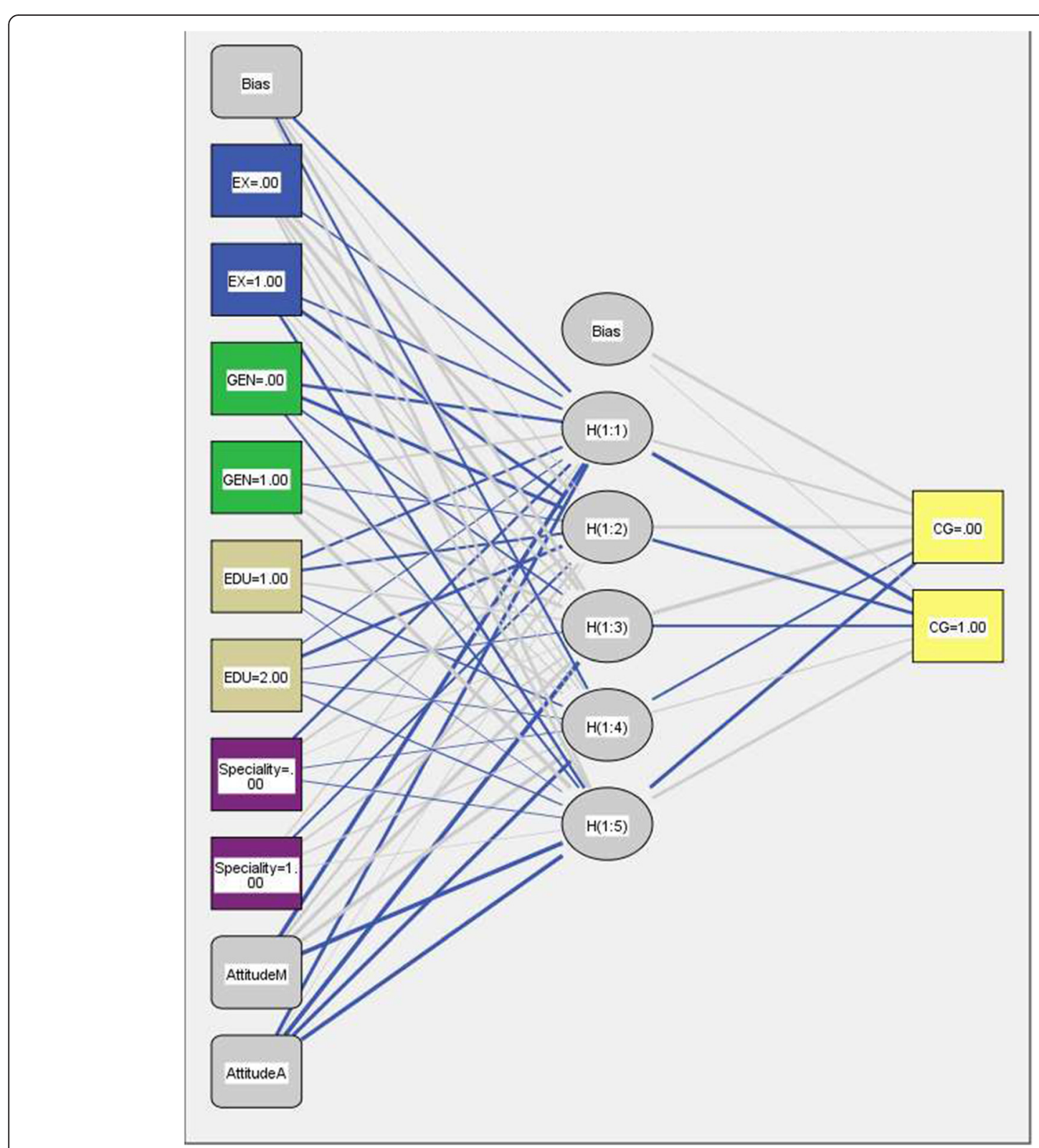

Fig. 1 Schematic view of the neural networks in non-linear function auditor's attitude toward corporate governance 


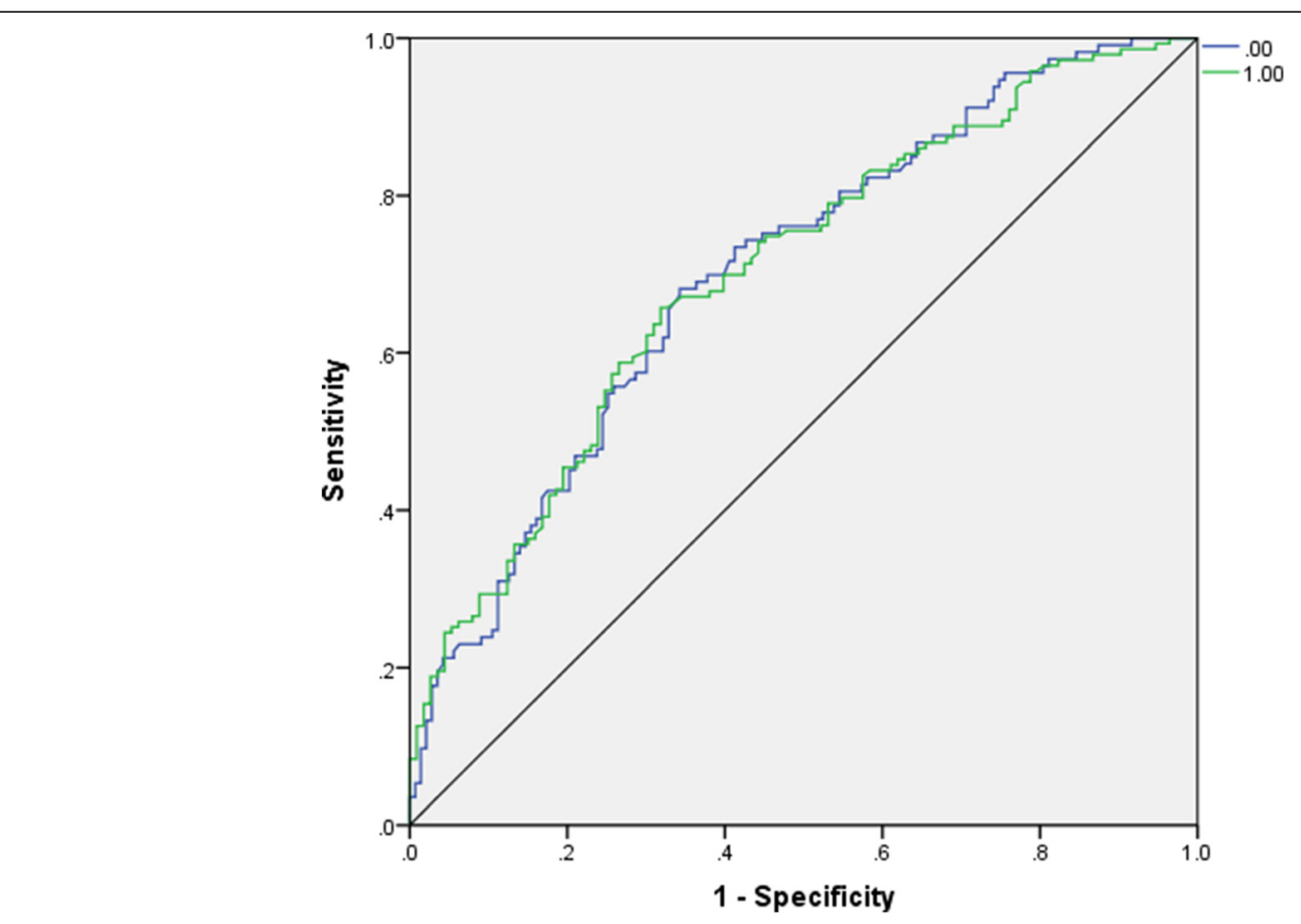

Fig. 2 ROC curve

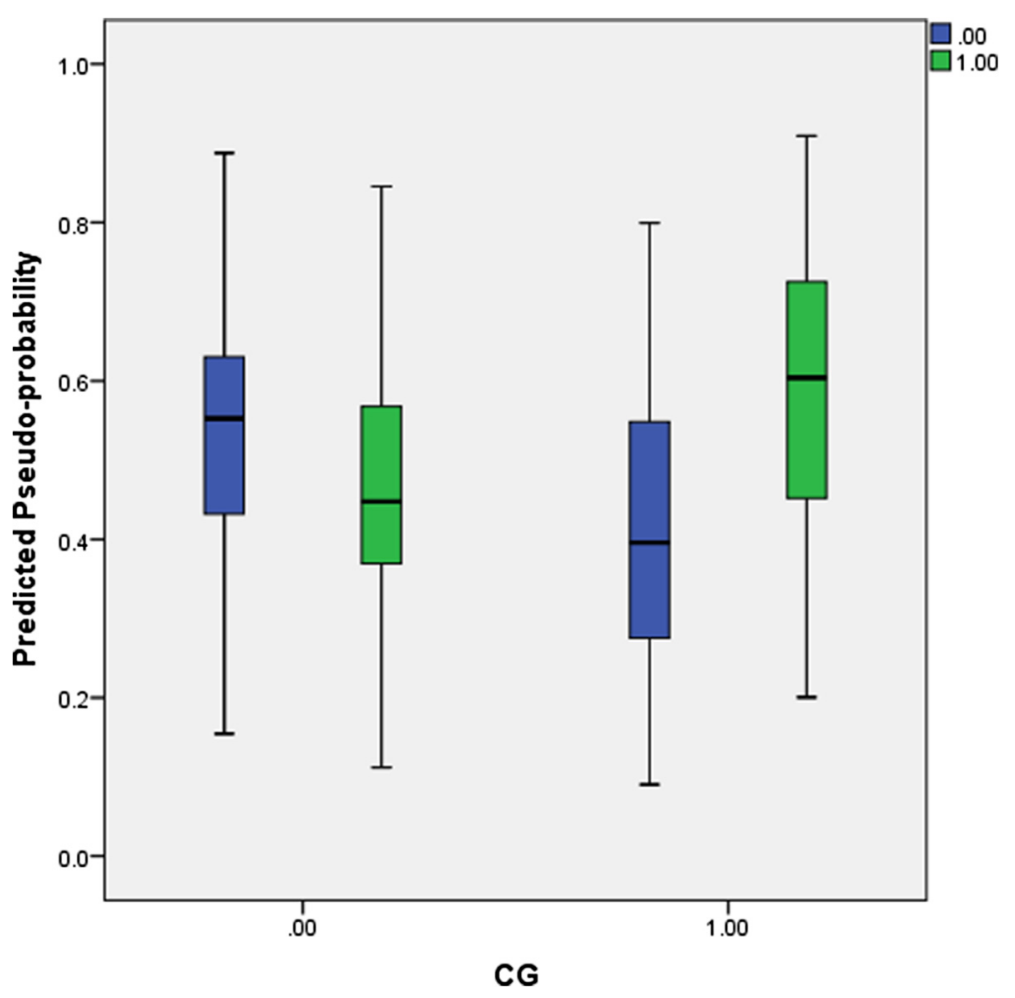

Fig. 3 Predicted pseudo-probability 
Table 9 Neural networks model results and MSE first and third hypothesis

\begin{tabular}{|c|c|c|c|c|c|}
\hline Sample & $\mathrm{N}$ & Percent & Percent Correct & Sensitivity & MSE in Probit Regression Results \\
\hline Training & 178 & 69.5 & 67 & - & - \\
\hline Testing & 78 & 30.5 & 65 & - & - \\
\hline Overall & 256 & 100 & - & .703 & .48 \\
\hline Sample & N & Percent & Percent Correct & Sensitivity & MSE in Probit Regression Results \\
\hline Training & 190 & 74.0 & 85 & - & - \\
\hline Testing & 66 & 26.0 & 83 & - & - \\
\hline Overall & 256 & 100 & - & .741 & .52 \\
\hline
\end{tabular}

of gender, profession, education, etc. Also, there is a significant difference between industry expert auditors' attitude and other auditors toward marketing activities. Finally, the attitude of auditors toward marketing had a positive significant relationship with attitude toward corporate governance. This shows that auditors with a positive attitude toward marketing maintain the interests of managers by performing marketing activities, and also find the desired client and make better judgments based on their expertise and agreement on the fees. Generally, our findings indicate that the influence of personality traits of auditors on their attitudes depends on attitudes toward the corporate governance mechanism and business environment. And results have verified concepts related to Parsons' theory of social action.

Previous studies on balancing all stakeholders' interests have shown that lack of conceptual framework has been one of the main problems in terms of auditors' attitude and consequently their behavior (Arel 2012; Broberg et al. 2013; Clow et al. 2009). This study has several theoretical and practical implications. First, it may be used by auditors and standard-setters as an assurance that not only are they involved in something that are named marketing or advertising, and even pricing, since the majority of their co-workers are doing marketing, but also they are actually finding it to be of importance, and are positively disposed toward it. Second, this study may be seen by marketing professionals as a signal that the doors of once closed professions are opening up for them, and that there might be an opportunity for mutually beneficial collaboration. Third, the paper provides important insights into emerging issues and developments in auditing and marketing that have clear relevance to auditing research and practice. Drawing on our analytical framework, we provide directions for further opportunities for research of social theories and auditing.

\section{Appendix}

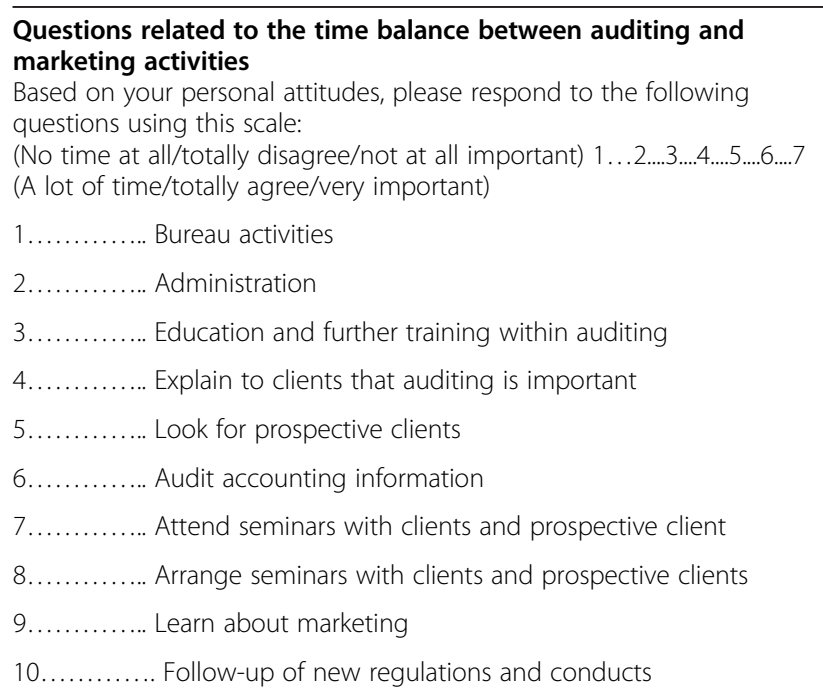

(Continued)

Questions related to attitude toward corporate governance mechanism

Based on your personal attitudes, please respond to the following questions using this scale:

(Not at all important) 1...2...3.... ....5...6....7 (Very important)

1 ........... Strengthening the role of non obliged managers in board of directors

2............ Strengthening supportive rules of stakeholders' interests

$3 . . . . . . . . .$. Preference of quality of auditing to its fees in practical procedures

4............ Expanding role and responsibilities of auditing committees

$5 \ldots \ldots \ldots \ldots . .$. Expanding role and responsibilities of internal auditors

6 ............ Defining social role of auditing for clients

7 ........... Defining the effect of mechanisms of corporate governance on auditing reports for clients

$8 \ldots \ldots \ldots \ldots$ Duality of CEO and chairman of the board

$9 . \ldots \ldots \ldots . . .$. Training managers in terms of corporate governance mechanisms 


\section{(Continued)}

\section{Questions related to entrepreneurial skills}

Based on your personal attitudes, please respond to the following questions using this scale:

(totally disagree) $1 \ldots .2 \ldots 3 \ldots . \ldots 4 . \ldots 5 . .6 \ldots . .7$ (totally agree)

1 ............ Usually, I try to accept the responsibility in team work.

$2 \ldots \ldots \ldots \ldots$ I am able to materialize my ideas.

3............ I am so tolerant.

4........... I believe I can influence over results.

$5 \ldots \ldots \ldots \ldots$ I am praised because of my ability in fast analysis of complicated situations.

$6 \ldots \ldots \ldots \ldots . .$. l'd rather work with an incompatible but proficient person than a friendlier and less efficient person.

$7 \ldots \ldots \ldots \ldots$. I can fire employees who are not profitable.

$8 \ldots \ldots \ldots \ldots$ I want to leave safe jobs with high payment to start my own business.

$9 \ldots \ldots \ldots \ldots \ldots$ I incline myself towards laborious tasks.

$10 \ldots \ldots \ldots . . .1$ can work for long hours.

$11 \ldots . . . . . .$. Strengthening the role of non obliged managers in board of directors

12 ........... Strengthening supportive rules of stakeholders' interests

13 ............ Preference of quality of auditing to its fees in practical procedures

$14 \ldots \ldots \ldots . .$. Expanding role and responsibilities of auditing committees

15........... Expanding role and responsibilities of internal auditors

$16 \ldots \ldots \ldots . .$. Defining social role of auditing for clients

$17 \ldots \ldots \ldots \ldots$. Defining the effect of mechanisms of corporate governance on auditing reports for clients

$18 \ldots \ldots \ldots . .$. Duality of CEO and chairman of the board

19........... Training managers in terms of corporate governance mechanisms

$20 \ldots \ldots \ldots \ldots$. In my colleagues' opinions, I am a creative person in solving problems.

$21 \ldots \ldots \ldots . .$. I have the ability of relating the whole and details of job.

$22 \ldots \ldots \ldots \ldots$ I have the ability of predicting the effect of current operations on future actions.

\section{Authors' contributions}

Both authors read and approved the final manuscript.

\section{Competing interests}

The authors declare that they have no competing interests.

Received: 28 February 2016 Accepted: 14 July 2016

Published online: 02 August 2016

\section{References}

Alavi Tabari, S. H., Mojtahed Zadeh, V., \& Bakhtyari, N. (2012). The effect of gender on quality of independent audit. Journal of Financial Accounting and Auditing, 13, 21-43 (In Persian).

Antoncic, B., \& Hisrich, R. D. (2004). Corporate entrepreneurship contingencies and organizational wealth creation. Journal of Management Development, 23, $518-550$

Arel, B. (2012). The influence of judges' attitudes on liability assessments related to failed audits exhibiting significant audit team over-time or significant use of off-shore auditors. Advances in Accounting, Incorporating Advances in International Accounting, 28, 201-208.
Biech, E. (2007). The business of consulting. New York: John Wiley and Sons.

Black, B. S., Love, I., \& Rachinsky, A. (2006). Corporate governance indices and firms' market values: time series evidence from Russia. Journal of Emerging Markets Review, 7, 361-379.

Broberg, P., Umans, T., \& Gerlofstig, C. (2013). Balance between auditing and marketing: an explorative study. Journal of International Accounting, Auditing and Taxation, 62, 57-70.

Cao, L., Li, W., \& Zhang, L. (2015). Audit mode change, corporate governance and audit effort. China Journal of Accounting Research, 8, 315-335.

Chaney, P. K., Jeter, D. C., \& Shaw, P. E. (2003). The impact on the market for audit services of aggressive competition by auditors. Journal of Accounting and Public Policy, 22, 487-516.

Chen, S. L., \& Liang, H. A. (2014). Cause Mapping of Simple and Complex Marketing Strategies. Journal of Business Research, 67, 2867-2876.

Clow, K. E., Stevens, R. E., Mconkey, C. W., \& Loudon, D. L. (2009). Accountants' attitudes toward advertising: a longitudinal study. Journal of Services Marketing, 23, 125-132.

Cornett, M. M., Marcus, A. J., \& Tehranian, H. (2008). Corporate governance and pay-for-performance: the impact of earnings management. Journal of Financial Economics, 87, 357-373.

DeTienne, K. B. Detienne, D. H., \& Joshi, S. A. (2003). Neural networks as statistical tools for business researchers. Organizational Research Methods, 6, 236-265.

Ducassy, I. (2015). Corporate social performance, ownership structure, and corporate governance in France. Research in International Business and Finance, 34, 383-396.

Durkheim, E. (1933). The division of labor in society. New York: Macmillan Press.

Etemadi, H., Ahmadpour, A., \& Moshashaei, M. (2015). Earnings per share forecast using extracted rules from trained neural network by genetic algorithm. Computational Economics, 46, 55-63.

Griffin, P. A., \& Lont, D. H. (2007). An analysis of audit fees following the passage of sarbanes- oxley. Asia-Pacific Journal of Accounting and Economics, 14, 161-192.

Hassas Yeganeh, Y., \& Dadashi, I. (2011). Investigating the effect of corporate governance on opinions of independent auditors. Journal of Management Accounting, 5, 65-73 (In Persian).

Hay, D., \& Knechel, W. R. (2010). The effects of advertising and solicitation on audit fees. Journal of Accounting Public Policy, 29, 60-81.

Healy, P. M., \& Palepu, K. G. (2003). How the quest for efficiency corroded the market. Harvard Business Review, 81(7), 76-85.

Höglund, H. (2015). Detecting earnings management with neural networks. Expert Systems with Applications, 39, 9564-9570.

Homocianu, D., \& Airinei, D. (2014). Business intelligence facilities with applications in auditing and financial reporting. Audit Financier, 12(117), 3-16.

Huang, T. C., Chiou, J. R., Huang, H. W., \& Chen, J. F. (2015). Lower audit fees for women audit partners in taiwan and why. Asia Pacific Management Review, 20, 219-233.

Ishak, A. M., Mansoor, N., \& Maruhun, E. N. S. (2013). Audit market concentration and auditor's industry specialization. Procedia - Social and Behavioral Sciences, 91, 48-56.

Kent, P., \& Stewart, J. (2008). Corporate governance and disclosures on the transition to international financial reporting standards. Journal of Accounting \& Finance, 48, 649-671.

Khorshidi, G., \& Moghaddami, S. (2002). The social marketing concept. Business Research, 28, 141-163 (In Persian).

Mahdavi, G., \& Daryaei, A. A. (2015). Giddens' structuration theory, corporate governance and audit marketing. Ludus Vitalis, 11, 1-7.

Malekian, E., Daryaei, A. A., Moshashaei, M., \& Imeni, M. (2015). Studies in development of accounting thought. Tehran: Termeh press (In Persian).

Miglani, S., Ahmed, K., \& Henry, D. (2015). Voluntary corporate governance structure and financial distress: evidence from Australia. Journal of Contemporary Accounting \& Economics, 11, 18-30.

Öhman, P., Häckner, E., \& Sörbom, D. (2012). Client satisfaction and usefulness to external stakeholders from an audit client perspective. Managerial Auditing Journal, 27(5), 477-499.

Palepu, K., \& Healy, P. (2003). The fall of Enron. Journal of Economic Perspectives, $17,3-27$.

Popescu, C. R., Popescu, V. A., \& Popescu, G. N. (2015). The entrepreneur's role in the performance growth of the financial audit activity in Romania. Amfiteatru Economic, 17(38), 228-246.

Rahmina, L. Y., \& Agoes, S. (2014). Influence of auditor independence, audit tenure, and audit fee on audit quality of members of capital market accountant forum in Indonesia. Procedia-Social and Behavioral Sciences, 164, $324-331$ 
Roche, G. (1998). Sociology of Talcot Parsons, translated by Abdul Hussein Nik Gohar (1st ed.). Tehran: Association of publication of Tebian (In Persian).

Sarwoko, I., \& Agoes, S. (2014). An empirical analysis of auditor's industry specialization, auditor's independence and audit procedures on audit quality: evidence from Indonesia. Procedia - Social and Behavioral Sciences, 164, 271-281. Steponaviciute, J., Zvirblis, A., \& Zumeriene, L. (2010). Analysis of audit market and audit firms activity in Lithuania. Annales Universitatis Apulensis Series Oeconomica, 12, 300-313.

Stiglbauer, M., \& Velte, P. (2012). Audit market concentration and its influence on audit quality. International Business Research, 5, 146-161.

Tavakol, M., \& Dennick, R. (2011). Making sense of cronbach's alpha. International Journal of Medical Education, 2, 53-55.

Tremblay, M. S., \& Malsch, G. B. (2016). Gender on board: deconstructing the "legitimate" female director. Accounting, Auditing \& Accountability Journal, 29(1), 165-190.

Watts, R., \& Zimmerman, J. (1986). Positive accounting theory. Englewood Cliffs: Prentice-Hall.

Yuan, R., Cheng, Y., \& Ye, K. (2016). Auditor industry specialization and discretionary accruals: the role of client strategy. The International Journal of Accounting, 51, 217-239.

\section{Submit your manuscript to a SpringerOpen ${ }^{\mathcal{O}}$ journal and benefit from:}

- Convenient online submission

- Rigorous peer review

- Immediate publication on acceptance

- Open access: articles freely available online

- High visibility within the field

- Retaining the copyright to your article

Submit your next manuscript at $\gg$ springeropen.com 